\title{
Analysis of the Impact of Growing Organised Retail Sector over Small Retail Stores in Raipur City
}

\author{
Vikas Dua $^{1}$, Anju Verma ${ }^{2}$ \\ ${ }^{1}$ Department of Management and Commerce, AVS Presidency International College, Raipur (CG)
}

\begin{abstract}
Economy of India is $7^{\text {th }}$ largest in the world in the terms of GDP and is expected to grow with 7\%. Retail industry accounts about 22\% of the total GDP of the country and it contributes to $8 \%$ of the total employment. The retail industry in India is one of the fastest growing industries with a growth rate of 10\%. This comprises of both organised and unorganised sector. Though the contribution of the organised sector in retail industry is about $8 \%$ but is expected to grow at a faster pace. Similar is the case with the different states in India. In 2001 Raipur became the capital of the Chhattisgarh and since then the economy of Raipur has seen a great development and change. In Raipur there are 6 shopping malls, more than 20 small and big departmental stores along with various traditional small and big mom n pop stores. This research paper makes a modest attempt to study the changing trends of retail industry. To know whether there is any affect on traditional retailers and if yes then to what extent. The study was done with the view point of both the small retailers and the customers. This paper also focuses on to know what steps the traditional or unorganised retailers take to survive.
\end{abstract}

Keywords: Retail Industry Growth, Impact on Small Retailers, Customers, Challenges and Strategies.

\section{Introduction}

In World Bank ,s growth outlook for 2015-16 India has topped for the first time as the economy has grown with $7.3 \%$ in $2014-15$ and expected to grow $7.5-8.3 \%$ in $2015-16$. Indian economy is $7^{\text {th }}$ largest in the world in terms of nominal GDP and $3^{\text {rd }}$ largest in the terms of purchasing power parity. The service sector in Indian economy which contributed to $57 \%$ of GDP in $2012-13$ is again a fastest growing sector in the world with the annual growth rate of $9 \%$ since 2001 . The service sector includes various sub sectors like energy and power, infrastructure, retail, tourism and banking and finance. Among all this sectors retail market in India is growing with fast pace.

According to A. T. Kearney, a US based global management consulting firm India is the fourth most attractive nation for retail investment among 30 flourishing markets. In 2015 India has $\$ 600$ billion worth of retail market. The total contribution of the retail industry in the GDP is between $14 \%-20 \%$. India is one of the top five retail market in the world by economic value and is estimated to be US $\$ 450$ billion. Indian retail market is projected to reach to reach $\$ 1.3$ trillion by 2020 .

\section{Retail Sectors}

Indian Retail industry can be broadly classified into two sectors namely organised retail and unorganised retail. In the present scenario the organised sector constitute only $8 \%$ and remaining $92 \%$ is left with unorganised retail sector.

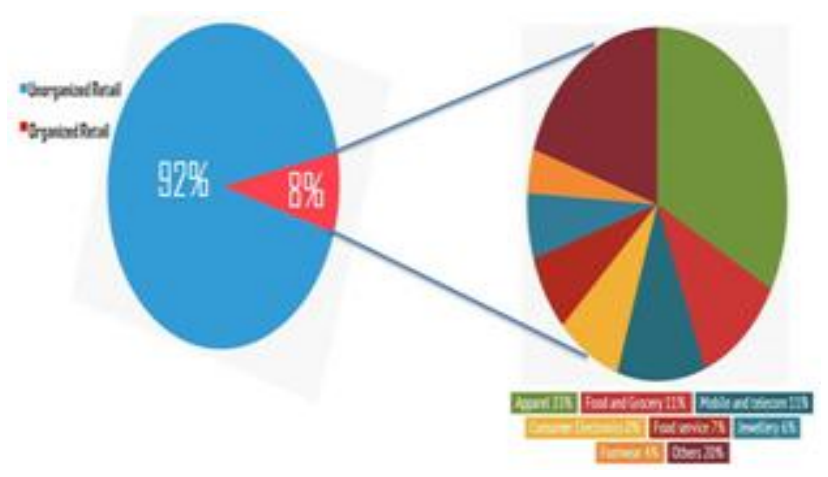

Unorganised retail sector

Unorganised retail Sector consist of large no of small retailers considting of local kirana shops, owner manned general stores, chemists, footwear shops, apparel shops, paan \& beedi shops, hand-cart hawkers, pavement vendors etc. It was found in the studies that organised sector is expected to grow with the pace of $10 \%$. Although organised sector is growing with the higher pace traditional retailers or

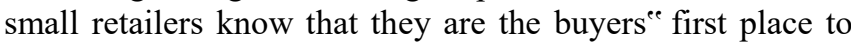
shop estimated to be 13 million by Technopack Advertisers Pvt. Ltd.. The classification of the unorganised retailing sector is as follows:

\begin{tabular}{|c|c|}
\hline Categories Of Shops & Types of Work Done \\
\hline $\begin{array}{c}\text { Fruits and Vegetable } \\
\text { seller }\end{array}$ & Sells fruit and vegetables \\
\hline Food Stores & $\begin{array}{l}\text { Seller of dairy products and breveges along } \\
\text { with the bakery products. }\end{array}$ \\
\hline $\begin{array}{l}\text { Non -Vegitable } \\
\text { Stores }\end{array}$ & Sellers of non vegetarian products \\
\hline Kirana 1 & $\begin{array}{l}\text { Sellers of home and personal care, dairy and } \\
\text { processed food beverages and bakery } \\
\text { products. }\end{array}$ \\
\hline Kirana 2 & $\begin{array}{l}\text { Sells all products of kirana } 1 \text { along with } \\
\text { pulses, cereals, spices and edible oils. }\end{array}$ \\
\hline Apparel & $\begin{array}{l}\begin{array}{l}\text { Seller of all king of garments for all age } \\
\text { group. }\end{array} \\
\end{array}$ \\
\hline Footwear & Seller of all foot wears for all age group. \\
\hline Customer Dura & Seller of all kinds of electronic, IT produc \\
\hline
\end{tabular}




\section{International Journal of Science and Research (IJSR) \\ ISSN (Online): 2319-7064}

Index Copernicus Value (2013): 6.14 | Impact Factor (2014): 5.611

\begin{tabular}{|c|c|}
\hline & and durable products. \\
\hline Furnishing & Sells upholstery and home lines products. \\
\hline Hardware & Sells tiles, door fittings and sanitary wares. \\
\hline General Mechanize & $\begin{array}{c}\text { Sells all lighting, stationary, toys, gifts and } \\
\text { crockery. }\end{array}$ \\
\hline
\end{tabular}

\section{Organised Retail Sector}

India got started with the organised chain of retailing in just few years ago, it is at nascent stage. The strength of organise retailing lies in the resource availability as it can translate into efficient supply chain management, leading to faster inventory turnover which results in improve button lines. The various existing players like, Bharti, Reliance Retail, Essar, Shopper's stop and Aditya Birla group are endeavouring to consolidate their markets, others such as Mohindra \& Mohindra, Parsavnath \& DLF, Hero Honda \& Indiabulls have announced plans to enter the organised retail sector.

Organised sector is growing with a faster rate of $40 \%-50 \%$. On 11 January 2012 single brand retail in India was approved in order to increase competition and innovation. This reform was to seek attractive investment in operation and marketing, increasing and improving the availability of goods for customer, encouraging the increased source of goods from India and to boost up competitiveness of Indian enterprises through access of global designs. In this declaration, India required single retail branding with 51\% of foreign ownership, to supply at least $30 \%$ of the value of products from Indian small, village and cottage industries, artisans and craftsmen.

\begin{tabular}{|c|c|}
\hline Indian Retail Group & Market Reach in 2011 \\
\hline Pantaloon Retail & 65 stores and 21 factory outlets in 35 cities \\
\hline Shoppers Stop & 51 stores in 23 cities \\
\hline Spencers Retail & 200 stores in 45 cities \\
\hline Reliance Retail & $\begin{array}{c}708 \text { mart and supermarkets, 20 wholeshale } \\
\text { stores in 15 cities, 508 fashion and } \\
\text { lifestyle. }\end{array}$ \\
\hline Bharti Retail & 74 Easyday Stores. \\
\hline Birla More & 575 stores \\
\hline Tata Trent & 59 Westside stores and 13 hypermarkets. \\
\hline Lifestyle Retail & 15 stores and 8 home centers. \\
\hline Future Group & 193 stores in 3 cities. \\
\hline
\end{tabular}

\section{Growth of Retail Sector:}

In 1997 India allowed Foreign Direct Investment (FDI) in cash and carry wholesale. To which approval requirement was relaxed and automatic permission was granted in 2006 . Indian retail attracted about $\$ 1.8$ billion in FDI, during 2000 to 2010 , which represents $1.5 \%$ of total investment flow in India. During 2006 to 2010 single brand retailing attracted 94 proposals, of which 57 were approved and implemented. Indian retail market is generating sales of about $\$ 470$ billion a year, out of which $\$ 27$ billion comes from organised retail sector like super markets, chain stores with centralised operations and shops in malls. The growth of Indian retail industry with organised sector will be $25 \%$ share by 2021 .

\section{Chhattisgarh and retail market:}

In the year 2001 Chhattisgarh was separated from Madhya Pradesh to become an independent state, with its capital Raipur. Raipur had an all round development as it has become a major hub for all kind of activities in every sector.
The lifestyle of the people also changed as they were developing with the state.

After 2001 the market structure of the place also changed. It became the centre for the growth of both organised and unorganised markets. It became the place for the retail and wholesale trading. With the growth of the market structure slowly and gradually small departmental stores and small mall opened with single retail branding like Lal Ganga shopping mall, Kishore mall, Big Bazar, Ravi Bhawan, Pantaloons, Anmol Super Bazar, etc. This stores provide an particular type of goods available to the customers under one roof.

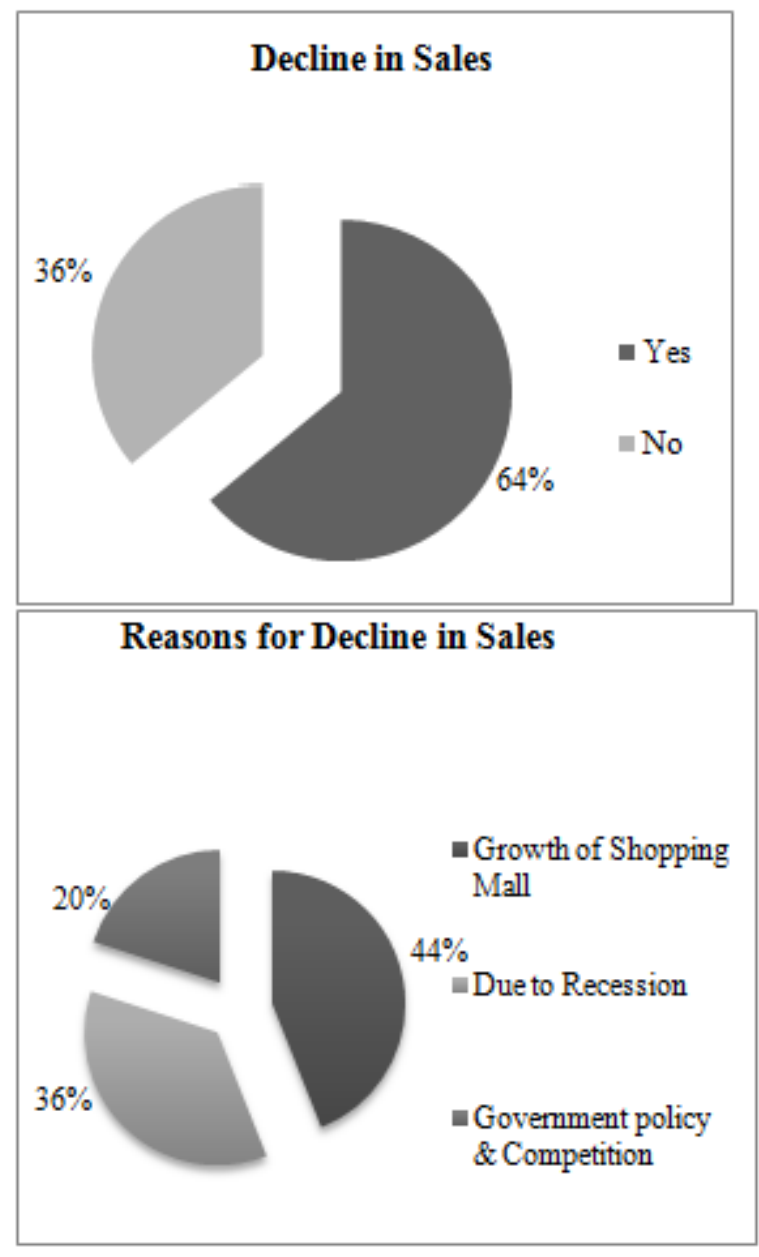

In 2007 City mall 36 was the first mall opened in the Raipur which gave a new dimension for shopping and hangouts for the customers and the consumers of the city. Later R. K mall, Megneto, Colors Mall, City Center, Millanium Plaza, Ambuja city Center, Dominos, etc were the projects which came into existence by 2011. They came with the various brands like Fab India, Habib's, Domino 's Pizza, Pizza hut, KFC, Wrsngler, nike, Globus, BIBA, Easy Day, D Mart, Shoppers Stop, Spencer, Inox, Glitz, PVR, etc. They provided all kinds of goods required by a person under one roof with an idea of shopping with entertainment. In June 2011, first cash and carry wholesale store was opened with joint venture between Bharti Enterprises and Walmart Stores Inc, named Best Price Mordern Wholesale. 


\section{International Journal of Science and Research (IJSR) \\ ISSN (Online): 2319-7064}

Index Copernicus Value (2013): 6.14 | Impact Factor (2014): 5.611

\section{Literature Review}

Research made in Guwahati it was found that most retail outlets are strategizing to win customers through brand management techniques. They are expanding brand knowledge of customers by making efforts the retail brand and private label brands. The retailers are trying to win customers loyalty through, shopping solution ${ }^{\text {ee }}$ that they offer to their customers.

Further it was found that broad consumer base and ever increasing population have given the necessary push to the Indian retail industry to grow prodigiously. In other studies it was found that the retail scenario in India has undergone a complete transaction over the last one and a half decade. The main reasons being the availability of low real state cost, change in buying habits, increase in disposable income, increase in women empowerment, more emphasis on instant items and high business prospects with low level risk on investment. The most important challenges in Indian retail industry are regional and cultural diversity, so it affects the retail sector some limitation in mall and supermarket like they attract only middle and upper class people. Organized retailing has huge potential which could lead to higher GDP. Growth and generate employment.

In researches it was found that the Wall-marts, K-Marts and other retailers are adding grocery retailing to their general merchandise offerings. The goal is to become a one-step shopping center, attracting new customers by offering groceries and holding down cost by utilizing economies of scale. The retailer is rapidly adding private label brands to both its general merchandising and supermarkets aisles. U.S. retailers spend millions of dollars each year designing, building and refurbishing stores. Millions more are spent hiring, training, and compensating employees that interact with retail customers.

\section{Objective of Study}

- To study the impact over small retailers in terms of sales.

- To find out the major challenges imposed by the organised retailing on small retailers.

- To find out the strategies opted by small retailers to cope up with the challenges.

- To find out the factors provided by organised retailing that attract the customers.

\section{Research Methodology}

The study was confined only with the Raipur City in Chhattisgarh. The study was based on the source of primary data; it was collected by both small retailers (shop keepers) and the customers residing in Raipur city. The data collection tool was schedule for the small retailers and questionnaire for the customers. The total sample size for the study was 150 on which 50 respondents were form small retail stores and rest 100 were the customers in the Raipur city.

\section{Data Analysis and Findings}

The information was collected separately with the shopkeepers and the residents of Raipur city. The data so collected from the respondents are analysed in the presented in the form of tables and pie charts. After evaluating the information, findings are presented below with an outlook to find the answers of the objectives of the study. Presentation of charts is in the sequence of the objectives thereof.

a. First objective of the study was to find out the impact of organised retail sector over small retailers. According to the responses so collected, there was a negative impact over the small retailers as there sales decreased. About $65 \%$ of the respondents (small retailers) experienced decline in their sales, out of this $44 \%$ of the respondents said that there sales decreased due to growth of organised retailing, $36 \%$ of the respondents said decline in sales is due to the government policies and the competitions and rest $20 \%$ said that decline is due to recession.

b. Analysis of the various challenges imposed by the organised retailing over small retailers. These challenges were taken from the both types of respondents i.e. from the shopkeepers and customers.

The attempt was made to know the major challenges pose by the growth of organised retailing over the small retail stores. The analysis of this is shown in 3 charts: Chart 1 - reason for the success of the big retailers, Chart 2- challenges posed by organised sector and Chart 3- challenges before small retailers with respect to customers. It can be clearly seen that the major challenges before the small retailers are infrastructure containing $55 \%$ and $37 \%$ respectively in chart 1 and 2, followed by trained staff, offers as discount and design and display with $32 \%$ in chart $1,30 \%$ and $18 \%$ in chart 2 and $43 \%$ in chart 3 continued by pricing strategy with $13 \%$ in chart 1 , operational cost with $15 \%$ in chart 2 and in chart 3 cash memo and services $24 \%$ and price fixation and maintenance with $12 \%$ followed by the verity of products with $12 \%$.

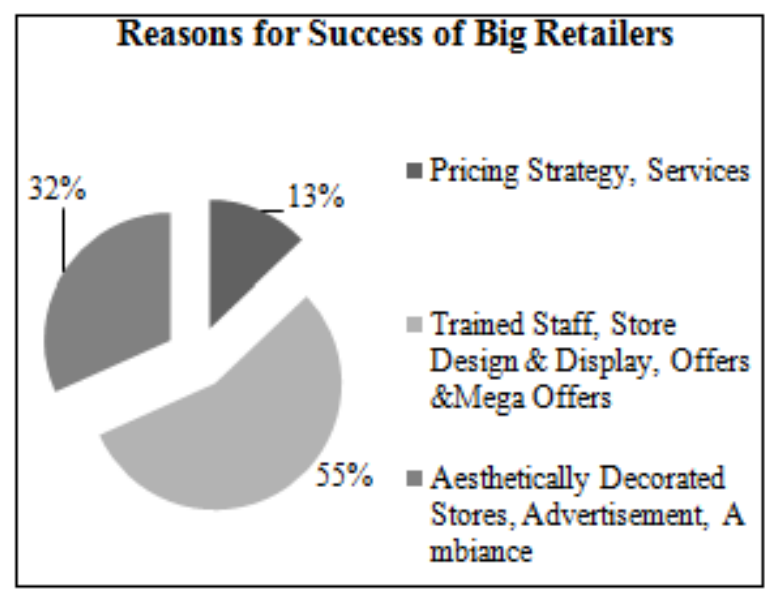




\section{International Journal of Science and Research (IJSR) \\ ISSN (Online): 2319-7064}

Index Copernicus Value (2013): 6.14 | Impact Factor (2014): 5.611

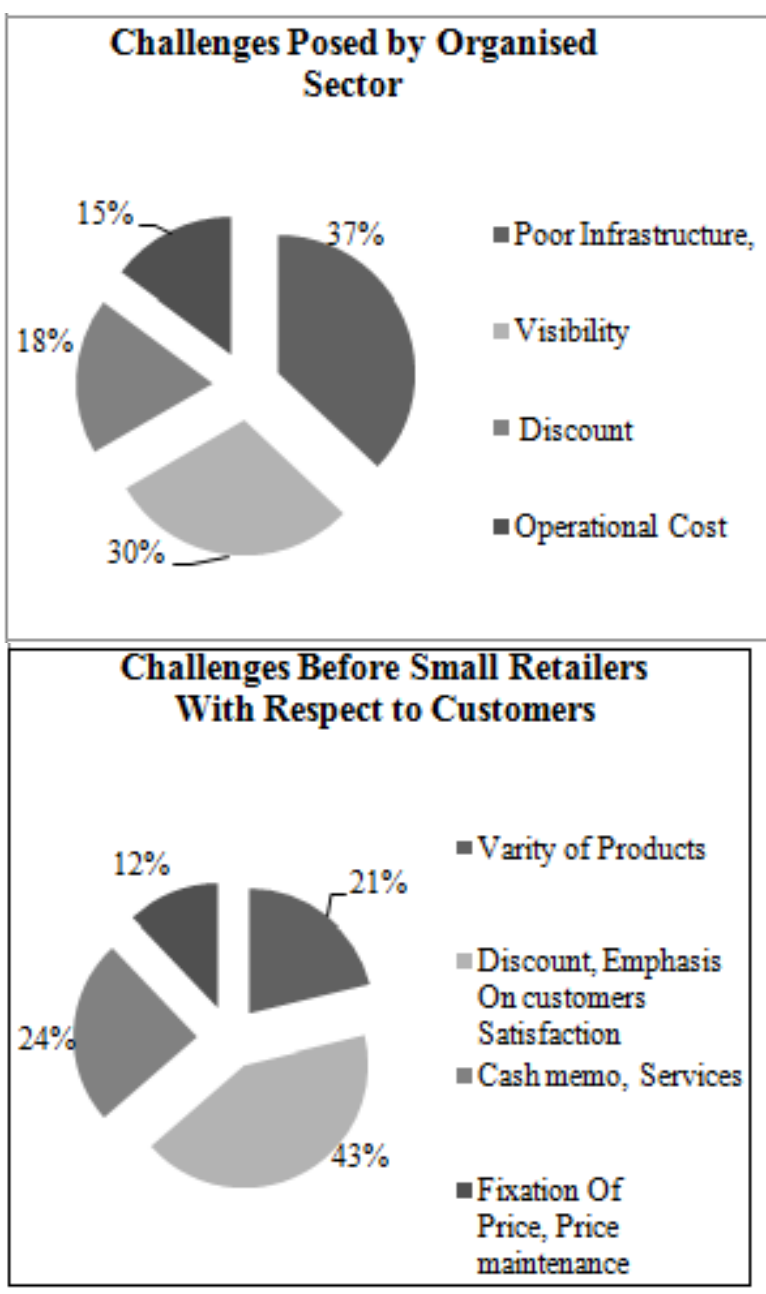

c. Analysing the various Strategies adopted by the small retail stores to overcome these challenges posed by the organised retail stores.

Analysis of the strategies was done with the view point of both small retailers and customers. It was found that in retailers point of view branded product, huge variety and stock maintenance came with $48 \%$ followed by discount with $32 \%$ and advertisement by $20 \%$. From the customer point $\mathrm{f}$ view $52 \%$ emphasis was made on the product variety, followed by rice and behaviour of the retailer with $24 \%$, $16 \%$ on credit facility and $8 \%$ on reliability and home delivery.

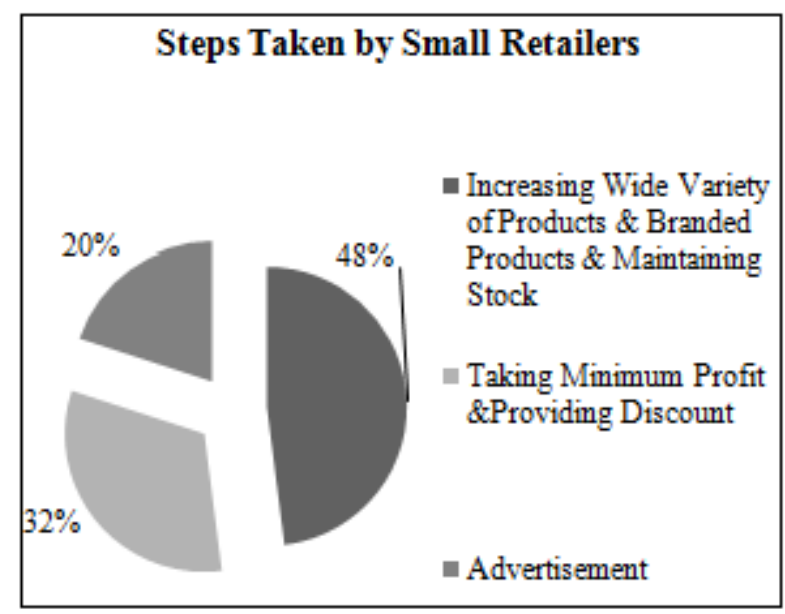

\section{Strategies for Small retailers by} Customers

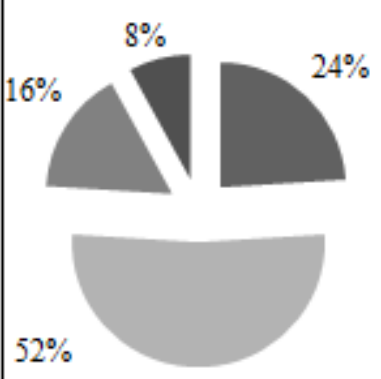

Reasonable price
,Infrastructure, Good
Behavior of Retailers
Products Variety and
Quality
Branded Products, Credit
Facility
- Reliability, Home
Delivery,

d. Analysing the features which differentiates the Small Retailers with Organised Sector and features which attract them.

This analysis was made to know the parameters with which the customers differentiate the organised and small retail sector and attracting features of the organised sector. The major attracting features of the organised sector are product variety and helpful staff with $60 \%$, followed by display and services by $24 \%$ and atmosphere by $16 \%$. Parameters of differentiating shows that the discounts, offers and parking facilities of the organised sector was liked most by the customers $32 \%$ as compared to small retailers with $4 \%$. In Product variety, ambiance, price and store display organised sector is liked by $31 \%$ as compared to the small retailers $8 \%$. Convenient and easy shopping shows that organised sector is liked by $27 \%$ as compared to small retailers $20 \%$ and credit facility is liked with $68 \%$ for small retailers and $10 \%$ by organised retailing.

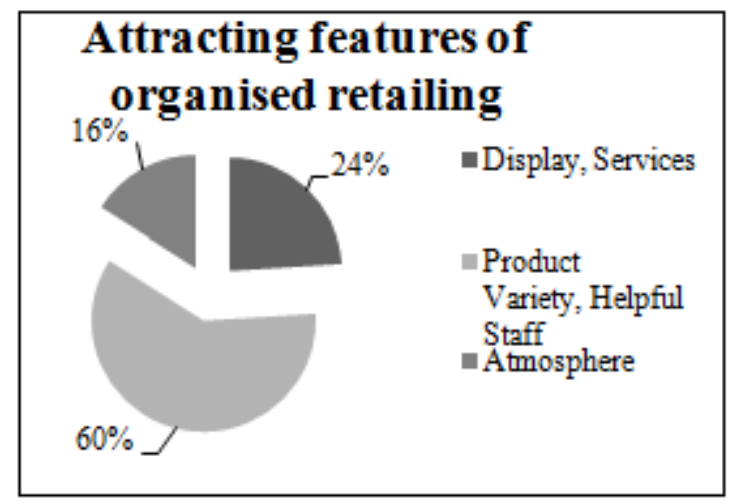




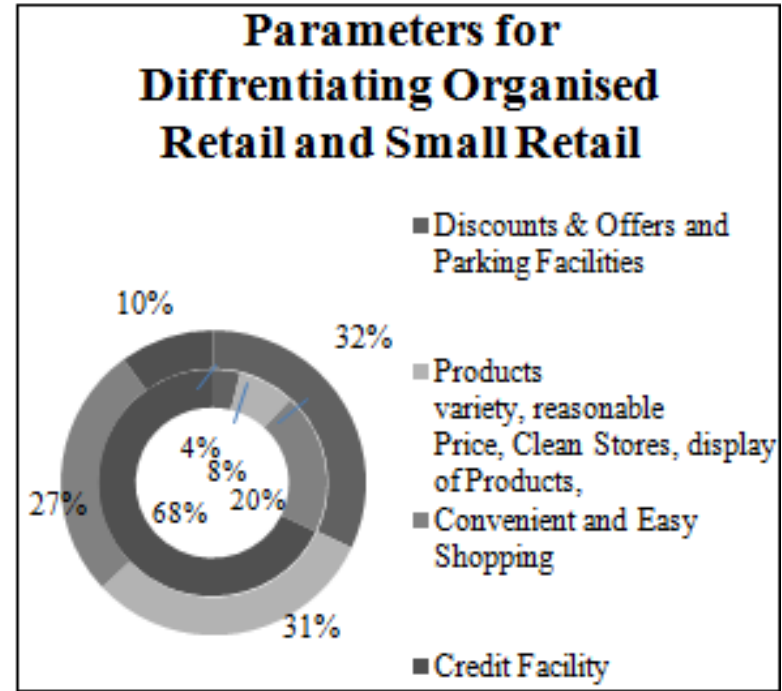

\section{Conclusion}

Growth and downfall are the two sides of a coin. As the organised sector in retail industry grows the unorganised sector breakdown but the tempo differs. Thought there was decrease in the sale of the small retail stores but the reliability and trust the customers have in them will help them in their survival. Small retail stores have adopted various strategies to cope up with the challenges posed by the organised sector. Customers are attracted towards malls and the departmental stores but the easy accessibility and customer relation of small retail stores gives a tough competition. With any kind of change in the industry there is always positive and negative with increase and decrease in the benefits if the competitors or the players. So in the end it can be said that growth of organised sector has an impact on small retail stores but the small retail stores has find new ways to face them.

\section{References}

[1] J. Baker, M. Levy, \& D. Grewal, Journal of Retailing Vol.68, pp.445-447, (1992),

[2] S. Bansal, "Marketing management" Kalyani Publishers, Ludhiana, pp.420-432, 2004.

[3] M. Amanatullah, "Principles of Modern Marketing ." Kalyani Publishers, New Delhi, pp.356\&357 , (1998).

[4] R. Agarwal \& M. Varma, "Marketing Management," Forward Publication Company, King of Books, Delhi, pp.277-294, (1998).

[5] P. Kotler, "Marketing Management," Pearson Education Pte. Ltd. Singapore, pp.535-545.

[6] G. Vedamani, "Retail Management," Jaico Publishing House, Mumbai, $4^{\text {th }}$ Edition,

[7] Indian council for research on international economic relations.

[8] http://www.icrier.org/ICRIERRetailReport22May08.pdf

[9] http://indiafdiwatch.org/fileadmin/India_site

[10] http://www.retailing.com

[11] http://business.mapsofindia.com/sectors/retail.html, Retail sector of Indian Economy.

[12] https://en.wikipedia.org/wiki/Retailing_in_India, Retailing in India.
[13] http://rajeshthambala.blogspot.in/2013/02/indian-retailindustry-2012-2013.html

[14] V. Handia; N Groveri; international journal of multidisciplinary resesrch; Volume 2; Pg no. 224-246 (2012)

[15] V Lakshmipathy; S. K. Basha; International journal of marketing, financial services and management research; Volume 1; PP 89-95 (2012)

[16]R Bhattacharya; IOSR journal of humanities and social sciences; Volume 5; PP 99-109 (2012)

[17] A. Hasan; S Mishra; LBS journal of management and research; PP 30-49 (2014)

[18] S. Karmugli; Dr. R Kannapa; international journal of advanced research in management and social science; volume 4; PP 69-78 (2015) 